Department of Morphology, Dental School of Bauru, Bauru, S.P. and Department of Histology, Institute of Biomedical Sciences, University of São Paulo, São Paulo, S.P.-Brasil

\title{
Metachromasia and Sulfate Uptake in the Polysaccharides of Some Organs of the Snake Xenodon merremii (WAGLER, 1824)
}

\author{
D. Sottovia-Filho, L. C. U. Junqueira and M. C. Leite-Ribeiro
}

Received May 1, 1972

\begin{abstract}
Summary. Using a combined cytophotometric-autoradiographic technique, the authors have detected in the snake Xenodon merremii an acid polysaccharidic complex in the serous acinar cells of upper labial salivary gland, the mucous cells of the excretory duct of Duvernoy's gland, the goblet cells of large intestine and intercellular matrix of tracheal cartilage. In a previous study, this same technique failed to demonstrate in this species the presence of mast cells, known to contain sulfated acid polysaccharides, suggesting that these cells do not occur in this animal species.
\end{abstract}

The ophidians constitute an animal group which has not been much studied, neither from histological nor physiological standpoint.

In earlier works (Sottovia-Filho and Junqueira, 1972; Sottovia-Filho et al., 1972), we have reported some histochemical observations on the granular acidophilic cells which we found in the connective tissue of Xenodon merremii. As we could not describe classical mast cells, by its cytochemical and physiological characteristics, an immediate interest arose in investigating the histochemical behavior of acid polysaccharides in other organs of this animal; the results of such investigation could then be used for a comparison with the negative results of histochemical tests which we applied in the search for polysaccharides, during the study of granular acidophilic cells.

There are few information on the histochemistry of ophidians. FERRI (1971) recently undertook an intensive analysis of the digestive tract of Xenodon merremii. Using histochemical and radioautographic methods this author demonstrated the presence of polysaccharides in some of the epithelial cells examined by him.

\section{Material and Methods}

Eighteen adult snakes Xenodon merremii,* with an average weight of $310 \mathrm{~g}$ $(220-540 \mathrm{~g})$ were used. Pieces of upper labial salivary gland, Duvernoy's gland, large intestine and trachea were fixed in Bouin's fluid and formaldehyde buffered to $\mathrm{pH}$ 7.0, an then submitted to routine paraffin embedding and microtomy procedures. The following methods were used:

\section{Metachromasia}

The sections were stained with $0.01 \%$ toluidine blue buffered to $\mathrm{pH} 6.0,5.0,4.0$ and 3.0, according to LANDSMEER (1951), and to $\mathrm{pH} 1.7$ according to FAVA-de-Moraes (1965) for $30 \mathrm{~min}$ and then mounted in the dye itself or in polyvinil pyrrolidone (PVP),

*We are indebted to the Department of Herpetology of Instituto Butantan, for providing the snakes. 
according to BuRstone (1957). The slides were examined under a Richert cytophotometer model 6003, maintaining the photometric field on the metachromatic structures. The transmission values were estimated varying the wavelength $(\lambda)$ within 480 and $630 \mathrm{~m} \mu$.

For each organ the measurements were performed on the cytoplasm of 10 different cells and on 10 different areas of the intercellular matrix of tracheal cartilage, for each $\mathrm{pH}$.

Samples of the dye, buffered to the different $\mathrm{pH}$, were diluted to a final concentration of $0.001 \%$ in Landsmeer's buffer, and then analysed with a spectrophotometer Zeiss, model $\mathrm{PMQ}$, for measurement of the ortochromatic absorption curve.

\section{Sulfate uptake}

Radioactive sodium sulfate, $\mathrm{Na}_{2} \mathrm{~S}^{35} \mathrm{O}_{4}$, ${ }^{*}$ carrier-free, at $\mathrm{pH}$ 7.0, was intraperitoneally injected in doses of 3 microcuries per gram of body weight. The animals were sacrificed $3,6,12$ and $24 \mathrm{hrs}$ after the injection and the organs were fixed in Bouin's fluid; paraffin embedded and cut at $5 \mu$.

The fluid emulsion method was used, according to MEssier and LeBLOND (1957), using the Ilford K 5 emulsion diluted to $1: 1$ in destilled water. After exposures of $10,16,22$, and 45 days, the sections were developed, fixed and stained with haematoxilin-eosin.

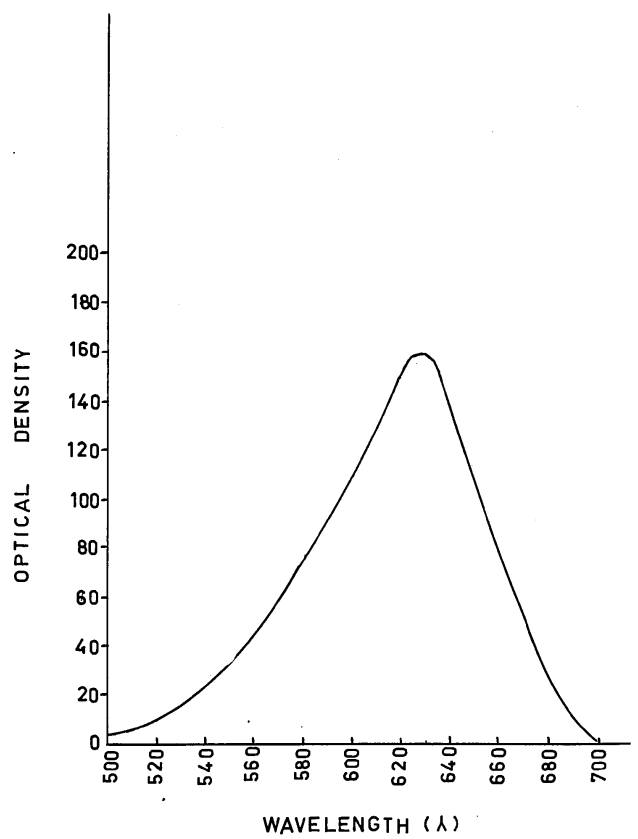

Fig. 1. Spectrophotometry. $0.001 \%$ toluidine blue in Landsmeer's buffer at $\mathrm{pH}$ 3.0.

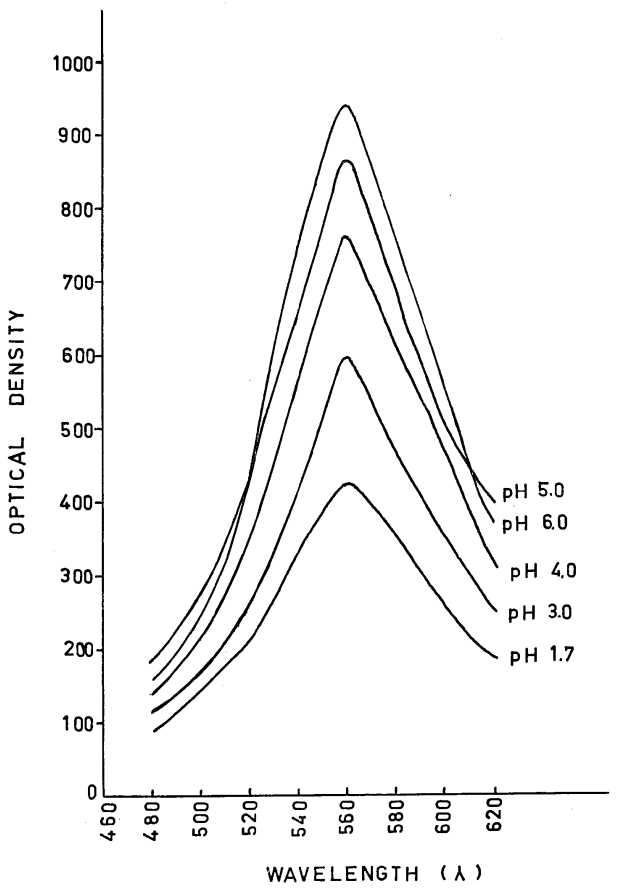

Fig. 2. Cytophotometry. Upper labial salivary gland, acinar serous cell.

\footnotetext{
* Labelled sodium sulfate was kindly supplied by Dr. Julio KIEFFER, Chief of Research at the Radiobiology Division of the Instituto de Energia Atômica of São Paulo.
} 


\section{Results}

\section{Metachromasia}

The transmission values for the several wavelengths determined, the optical density was calculated and the corresponding graphs were made, using the mean values obtained for the structure considered.

As the spectrophotometric results for the samples of the dye buffered to all $\mathrm{pH}$ always gave similar curves, with maximal extinction at $630 \mathrm{~m} \mu$, we will present here only the absorption spectrum of toluidine blue buffered to $\mathrm{pH} 3.0$ (Fig. 1). The results of the cytophotometric analysis performed in the several organs are presented in Figures $2-5$, where we can observe maximal extinction always occuring at $560 \mathrm{~m} \mu$.

Comparing the curves for the several structures stained with toluidine blue and the spectrophotometric curve

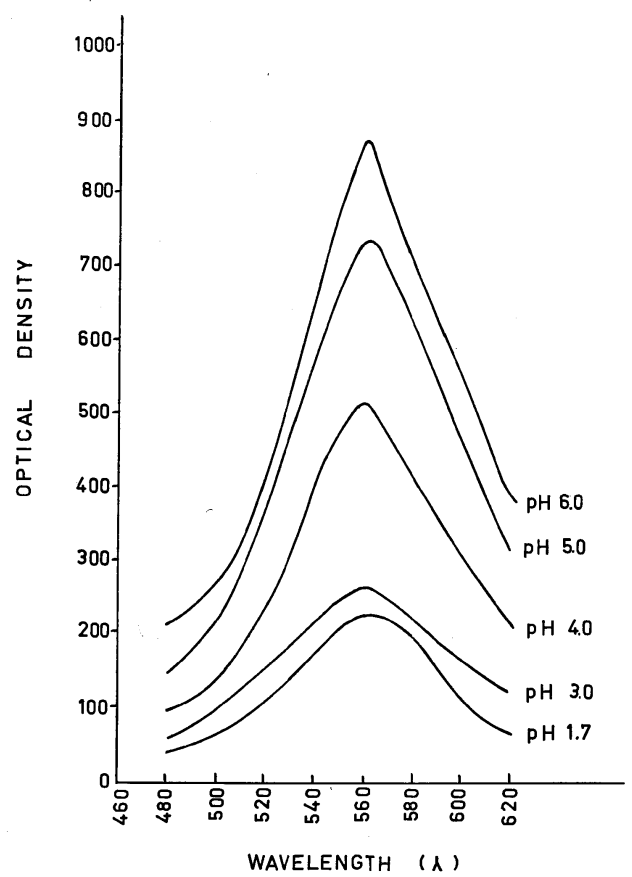

Fig. 4. Cytophotometry. Large intestine, goblet. cell.

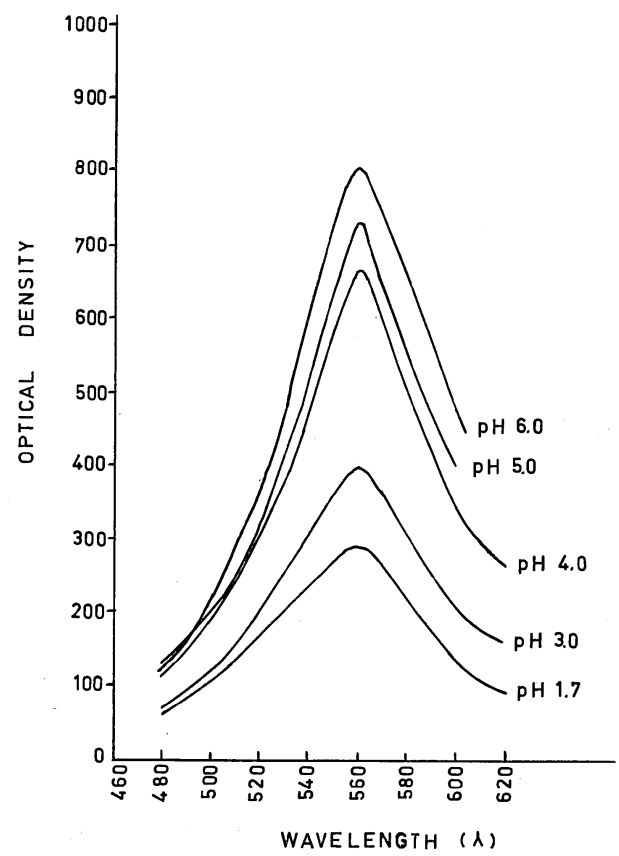

Fig. 3. Cytophotometry. Duvernoy's gland, mucous cell of the excretory duct.

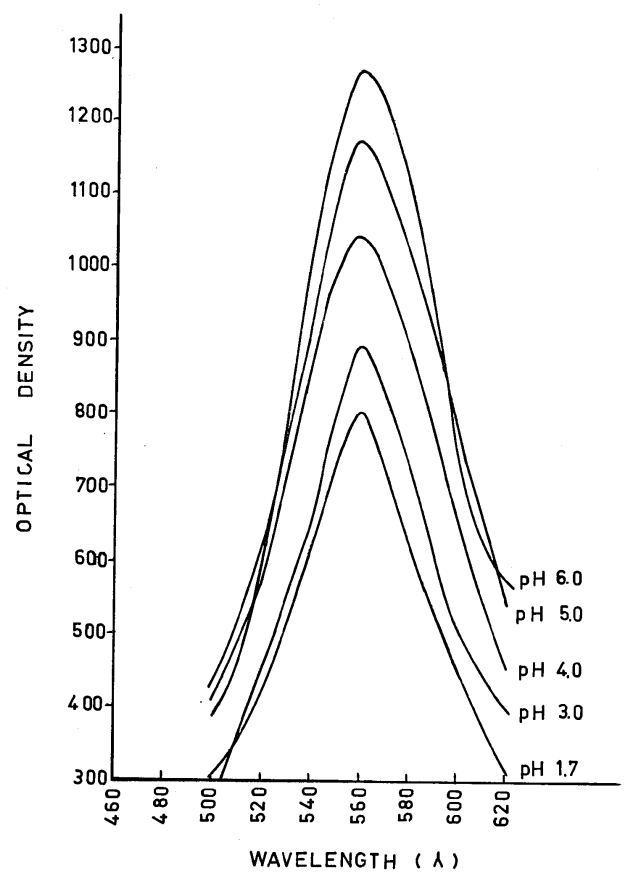

Fig. 5. Cytophotometry. Trachea, cartilage matrix. 
of the dye, a uniform deviation to the left is obscrved at all $\mathrm{pH}$ used demonstrating thus the presence of metachromasia.

Differences in the metachromatic staining could not be observed for the two

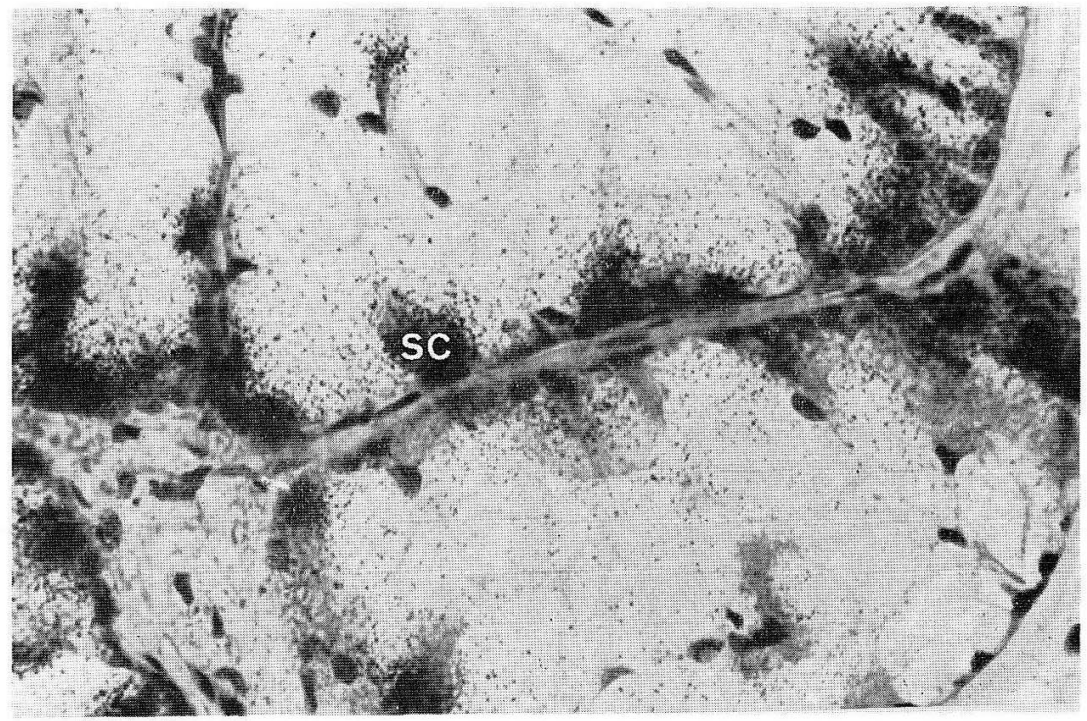

Fig. 6. Upper labial salivary gland. This gland is formed mainly by mucous cells that do not incorporate $\mathrm{S}^{35}$. The small serous cells $(S C)$ however show an intense uptake, as shown by abundant reduced silver grains over then. Twelve hours after the injection of $\mathrm{S}^{35}$. Exposure time $=22$ days. $\times 470$

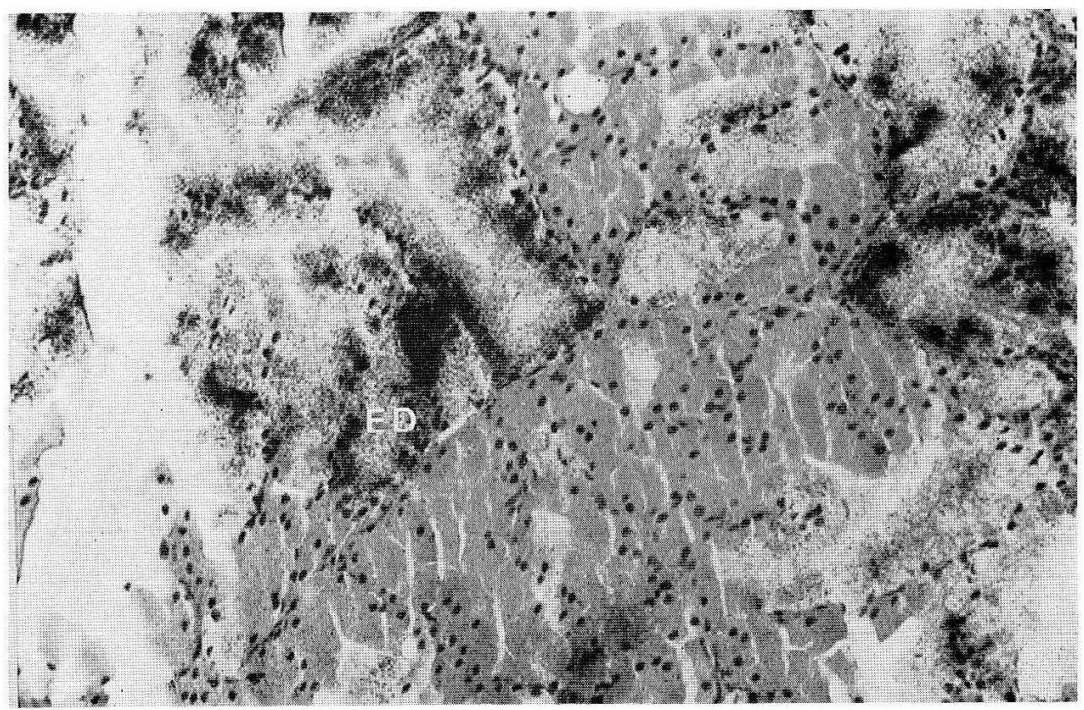

Fig. 7. Duvernoy's gland. "Loci" of radioactivity in the mucous cells of the excretory duct $(E D)$. The serous cells of the acini do not incorporate $\mathrm{S}^{35}$. Twelve hours after the injection of $\mathrm{S}^{35}$. Exposure time $=22$ days. $\times 170$ 
mounting media used.

These results therefore suggest that the serous acinar cells of upper labial salivary gland, the mucous cells of the excretory duct of Duvernoy's gland, the goblet cells of large intestine and the intercellular matrix of tracheal cartilage, contain acid polysaccharides.

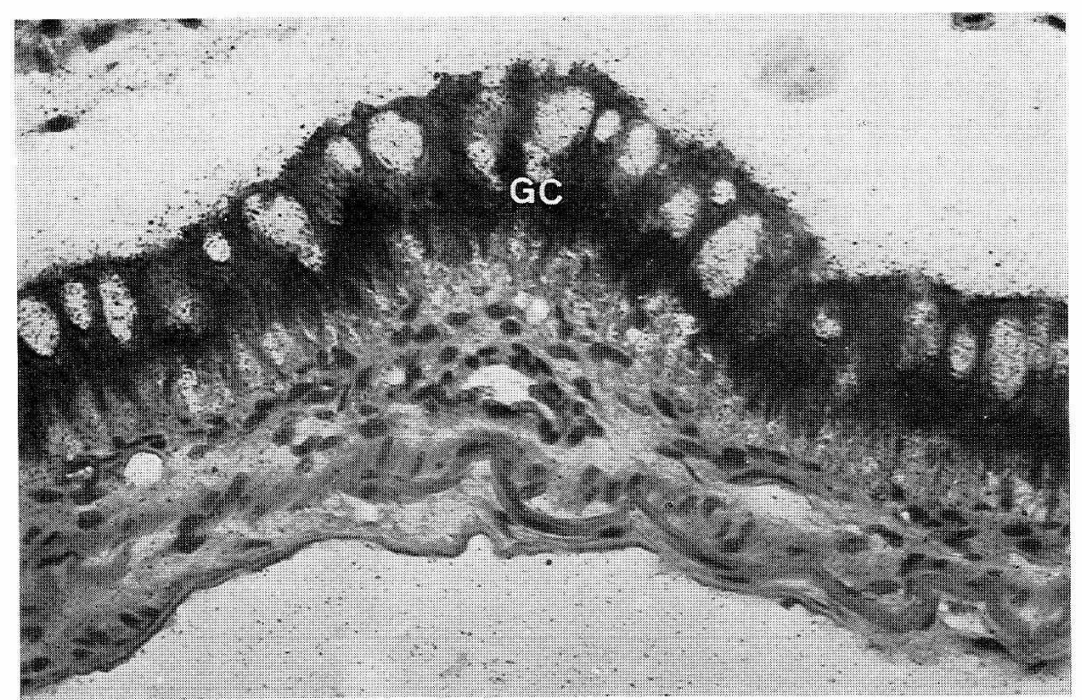

Fig. 8. Large intestine. Observe the intense uptake of $\mathrm{S}^{35}$ by the goblet cells (GC). Twelve hours after the injection of $\mathrm{S}^{35}$. Exposure time $=22$ days. $\quad \times 470$

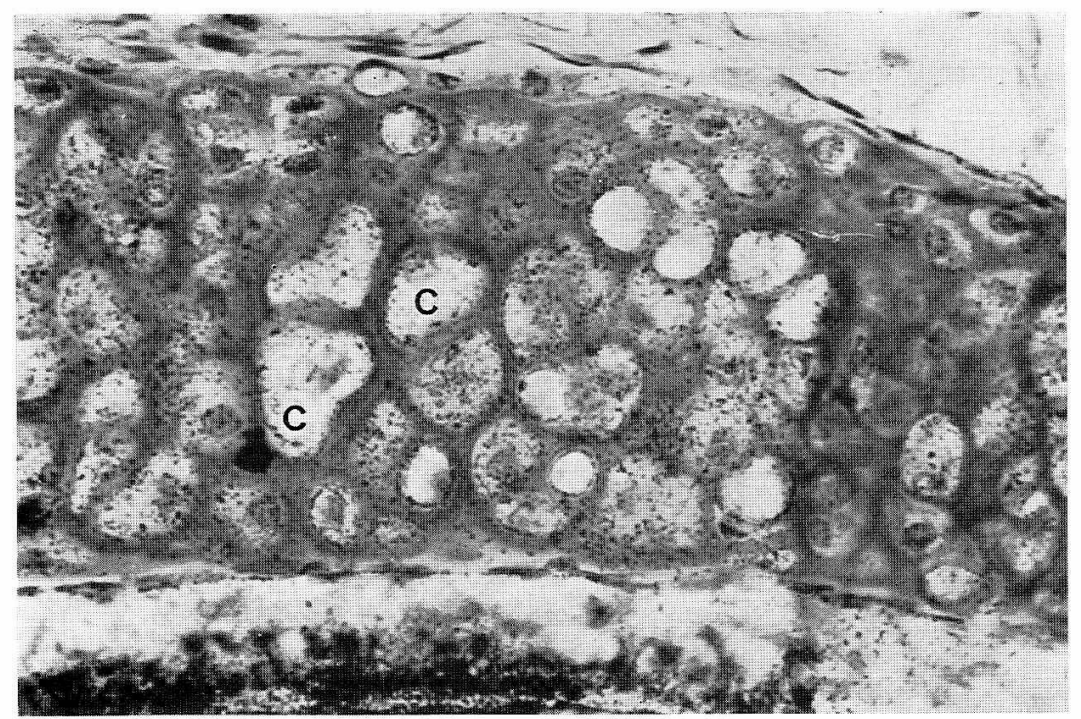

Fig. 9. Trachea cartilage. Incorporation of the $\mathrm{S}^{35}$ by the chondrocytes $(C)$. Few reduced silver grains can be observed in the intercellular matrix. Twelve hours after the injection of $\mathrm{S}^{35} . \quad$ Exposure time $=22$ days. $\quad \times 470$ 


\section{Sulfate uptake}

The uptake of sulfur radioactive isotope was observed in the same structures which presented metachromasia to toluidine blue, those structures which had been analysed cytophotometrically.

The studied cells presented a gradual uptake of isotope. Thus after $3 \mathrm{hrs}$ of the injection, a weak incorporation could be detected in the serous acinar cells of upper labial salivary gland and mucous cells of the excretory duct of Duvernoy's gland; in the goblet cells of the large intestine, "loci" of radioactivity could already be noticed in the supranuclear cytoplasm, corresponding to Golgi area. From 6 to 24 hrs, the uptake was increasingly higher and "loci" of radioactivity could be first noticed in the intracellular and later on in the extracellular secretion (Fig. 6-8).

The incorporation of $S^{35}$ by tracheal cartilage was very weak until 3 hrs after the injection. Very few silver grains could be observed in the cytoplasm of the chondrocytes. After 6 hrs the incorporation was a little stronger, but only after 12 hrs "loci" of radioactivity could be detected in the intercellular matrix, being more marked after 24 hrs (Fig. 9).

\section{Discussion}

A combined histochemical-autoradiographic technique has been used by many authors such as Bostron et al. (1953), Bostron and Odeblad (1953), Mancini and Lustig (1954), Mancini et al. (1955), Spicer et al. (1961), Kato and Airlin (1963) and FERRI (1971), to identify acid polysaccharides in tissues.

The results that we obtained in the serous acinar cells of upper labial salivary gland, mucous cells of the excretory duct of the Duvernoy's gland, goblet cells of large intestine and intercellular matrix of tracheal cartilage, by cytochemical and autoradiographic analysis, have reveled the presence of acid polysaccharides in these structures.

The metachromatic reaction observed by the use of toluidine blue, methylene blue and Azur A has been the main concern of several investigators. MichaELIs and GRANICK (1945), SyLVÉN (1954) and Lison (1960), using substrates with a high degree of purity, employed metachromasia in an attempt to differenciate the several types of polysaccharides, spectrophotometrically, according to the wavelength where maximal extinction can be observed.

When toluidine blue is used for detection of polysaccharides in histological sections, the metachromasia which is observed at $\mathrm{pH} 5.6$ and still present if the $\mathrm{pH}$ is lowered to 1.7, reveals the presence of sulfate groups; if it disappears at $\mathrm{pH} 1.7$, carboxyl groups are present (see Lison, 1960).

In our cytophotometric observation, despite of the use of toluidine blue buffered to several $\mathrm{pH}$, the peak of maximal extinction did not change, always occoring at $560 \mathrm{~m} \mu$ in the structures studied. This fact suggests the presence of sulfated polysaccharides in these structures. No conclusion as to the presence of non-sulfated (carboxylated) polysaccharides could be obtained.

It might be possible that these two types of polysaccharides coexist in the metechromatic structures studied. As a matter of fact the coexistence of two polysaccharides in three of the above mentioned structures was observed by FERRI (1971), who demonstrated the presence of sulfated and non-sulfated acid polysaccharides in 
the goblet cells of the digestive tract of Xenodon merremii, and ZAGo (1971), who observed an analogous situation in the serous cells of upper labial salivary gland and in mucous cells of the excretory duct of the Duvernoy's gland of several species of snakes.

Analysing the cytophotometric graphs of the various structures which we have studied, it can be noticed that optical density presents a great quantitative variation in relation to the different $\mathrm{pH}$ of the dye, as well as in relation to one single for the different structure analysed. In despite of these differences, it is impossible to make a quantitative analysis in this material for metachromatic staining does not follow Beer's concentration-absorption law, for the interaction of the metachromatic dye and substrate is not stechiometric.

The detection of radioactive sulfur in the metachromatic structures indicates the presence of sulfated acid polysaccharides in these sites. Its uptake by the cells is already observed $3 \mathrm{hrs}$ after the injection and increases with time, due to the continuous processes of captation and synthesis.

In the tracheal cartilage, the necessary time for "loci" of radioactivity to appear is greater, possibly because the processes of captation, synthesis and elimination of products is slower in the chondrocytes.

Our observations reinforce the validity of the combined technique (metachromasia plus sulfate uptake) for detecting acid polysaccharides in reptilian material. The absence of connective tissue cells presenting granules with sulfated acid polysaccharides further reinforce the view that this species does not contain mast cells.

\section{References}

Bostron, H. and E. Odeblad: Autoradiographic observation on the incorporation of $\mathrm{S}^{35}$ labelled sodium sulphate in the rabbit foetus. Anat. Rec. 115: 505-515 (1953).

Bostron, H., E. Odeblad and V. Friberg: A quantitative and qualitative autoradiographic study on the uptake of $\mathrm{S}^{35}$ labelled sodium sulphate in the skin of adult rat. Acta pathol. microbiol. scand. 32: 516-521 (1953).

Burstone, M. S.: Polyvinil pyrrolidone as a mounting medium for stain for fat and Azo-dye procedures. Amer. J. clin. Pathol. 28: 429-430 (1957).

Fava-de-Moraes, F.: Alguns dados morfológicos associados ao estudo histoquímico dos polissacarídeos em glândulas salivares de animais pertencentes às seguintes ordens: Marsupialia, Chiroptera, Primates, Edentata, Lagomorpha, Rodentia, Carnivora e Artiodactyla (Mammalia). Rev. Fac. Odont. S. Paulo 3: 231-290 (1965).

Ferri, S.: Contribuição ao estudo morfológico e histoquímico do esôfago, estômago e intestinos de Xenodon merremii (Wagler, 1824) Ophidia. São Paulo, Department of Histology of the Institute of Biomedical Sciences of São Paulo (1971). Thesis.

Kato, K. I. and J. L. Airlin: Aspects of mucopolysaccharides production in larval insect salivary cells. A combined cytochemical-radioautographic approach. J. Histochem. Cytochem. 11: 163-168 (1963).

Landsmeer, J. M. F.: Some colloid chemical aspects of metachromasia. Influence of $\mathrm{pH}$ and salts on metachromatis phenomena evoked by toluidine blue in animal tissue. Acta physiol. pharmacol. neerl. 2: 112-128 (1951).

Lison, L.: Histochimie et cytochimie animales: Principes et méthodes. 3ème ed. Paris, GauthierVillars, 1960. 
Mancini, R. E. y E. S. Lustig: Investigation autorradiográfica de la captacion del azufre radioativo. Rev. Soc. Argentina Biol. 30: 67-76 (1954).

Mancini, R. E., C. Nuñez y E. S. Lustig: Captacion del azufre radioativo ( $\left.\mathrm{S}^{35}\right)$ por el mucopolisacarideos del tecido conetive adulto, embrionario y de cultivo "in vitro". Rev. Soc. Argentina Biol. 31: 222-241 (1955).

Messier, B. and C. P. Leblond: Preparation of coated radioautographs by dipping sections in fluid emulsion. Proc. Soc. Exp. Biol. Med. 96: 7-10 (1957).

Michaelis, L. and S. Granick: Metachromasy of basic dyestuffs. J. Amer. Chem Soc. 67: 1212-1219 (1945).

Sottovia-Filho, D. and L. C. U. Junqueira: Studies on the connective tissue of the snake Xenodon merremii (Wagler, 1824). Arch. histol. jap. 34: 143-154 (1972).

Sottovia-Filho, D., L. C. U. Junqueira, J. Carneiro and M. C. Leite-Ribeiro: Studies on the granular acidophilic cells in the connective tissue of the snake Xenodon merremii (Wagler, 1824). Rev. Brasil. Biol. (1972, in press).

Spicer, S. S., R. L. Swan and H. J. Burtoner: Comparison of basofilia with $\mathrm{S}^{35}$ label in normal and methylated mucopolysaccharides. Lab. Invest. 10: 256-264 (1961).

Sylvén, B.: Metachromatic dye-substrate interaction. Quart. J. microsc. Sci. 95: 327-358 1954).

Zago, D. A. : Estudo morfológico e histoquímico de glândulas salivares relacionadas com a evolução da função venenosa nos ofidíos. São Paulo, Department of Histology of the Institute of Biomedical Sciences, University of São Paulo. (1971). Thesis.

Dr. Dagoberto SotTovia-Filho

Department of Morphology

Faculdade de Odontologia de Bauru da

Universidade de São Paulo

Caixa Postal 73

Bauru-17.100-S.P.-Brasil 